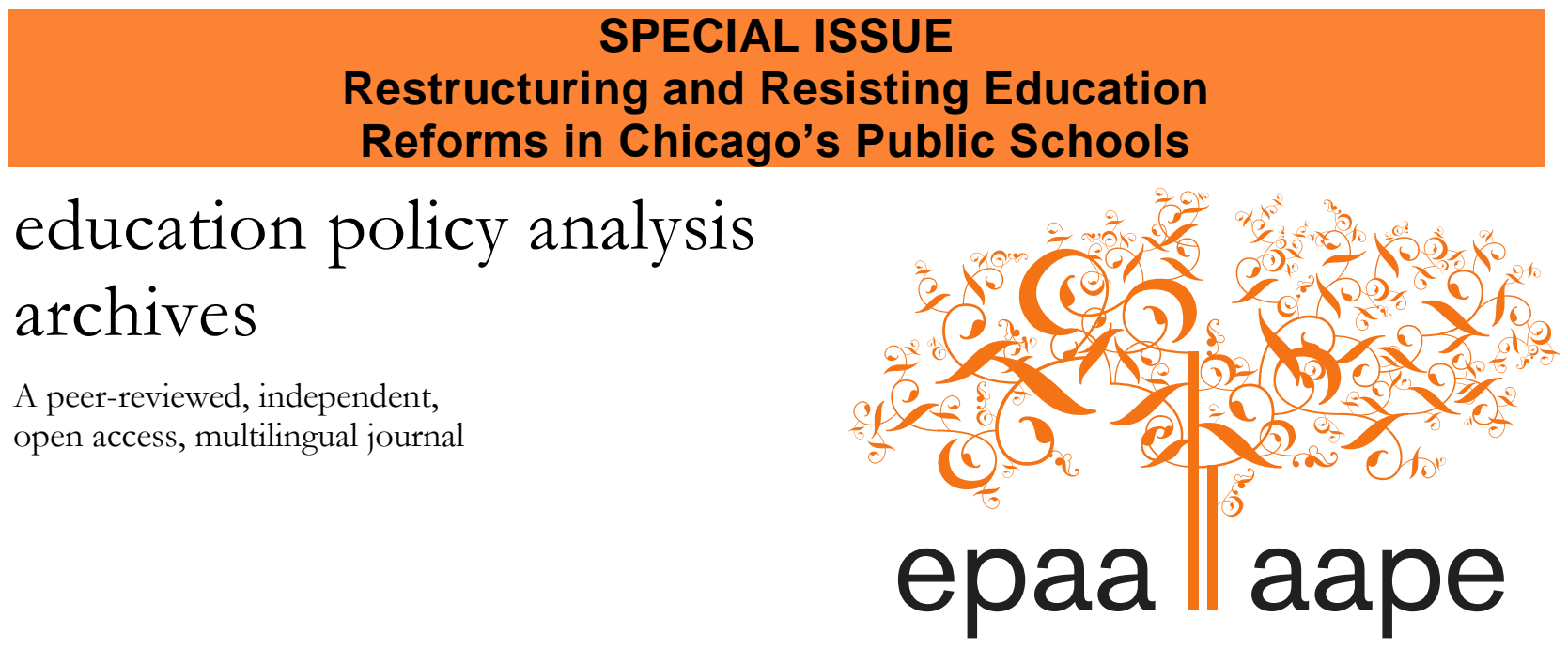

Arizona State University

\title{
The Promise and Realities of Pay for Success/Social Impact Bonds
}

\author{
Kenneth J. Saltman \\ University of Massachusetts Dartmouth \\ United States
}

Citation: Saltman, K. (2016). The promise and realities of Pay for Success/ Social Impact Bonds. Education Policy Analysis Archives, 25(59). http://dx.doi.org/10.14507/epaa.25.2640 This article is part of EPAA/AAPE's Special Issue on Restructuring and Resisting Education Reforms in Chicago's Public Schools, Guest Edited by Dr. Federico Waitoller and Rhoda R. Gutierrez.

\begin{abstract}
This article considers proponents' arguments for Pay for Success also known as Social Impact Bonds. Pay for Success allows banks to finance public services with potential profits tied to metrics. Pay for Success has received federal support through the Every Student Succeeds Act of 2016 and is predicted by 2020 to expand in the US to a trillion dollars. As school districts, cities, and states face debt and budget crises, Pay for Success has been advocated by philanthropists, corporate consulting firms, politicians, and investment banks on the grounds of improving accountability, cost savings, risk transfer, and market discipline. With its trailblazing history in neoliberal education, Chicago did an early experiment in Pay for Success. This article provides a conceptual analysis of the key underlying assumptions and ideologies of Pay for Success. It examines the claims of proponents and critics and sheds light on the financial and ideological motivations animating Pay for Success. The article contends that Pay for Success primarily financially benefits banks without providing the benefits that proponents promise. It concludes by
\end{abstract}


considering Pay for Success in relation to broader structural economic considerations and the recent uses of public schooling to produce short-term profit for capitalists.

Keywords: Pay for Success; Social Impact Bonds; Chicago School Reform; Neoliberal Education; Corporate School Reform; Venture Philanthropy

\section{La promesa y las realidades de Pay For Success/Social Impact Bonds}

Resumen: En este artículo se consideran los argumentos de los proponentes de Pay for Success, también conocidos como Social Impact Bonds. Pay for Success permite a los bancos financiar servicios públicos con beneficios potenciales vinculados a métricas. Pagar por el Éxito ha recibido apoyo federal a través de la Ley de Todos los Sucesos Sucesivos de 2016 y está previsto para 2020 para expandirse en los EE.UU. a un billón de dólares. A medida que los distritos escolares, las ciudades y los estados se enfrentan a crisis de deuda y presupuesto, Pay for Success ha sido defendido por filántropos, empresas de consultoría corporativa, políticos y bancos de inversión con el fin de mejorar la rendición de cuentas, ahorro de costos, transferencia de riesgos y disciplina de mercado. Con su historia pionera en la educación neoliberal, Chicago hizo un experimento temprano en Pay for Success. Este artículo provee un análisis conceptual de las suposiciones e ideologías fundamentales de Pay for Success. Examina las afirmaciones de los defensores y críticos y arroja luz sobre las motivaciones financieras e ideológicas que animan a Pay for Success. El artículo sostiene que pagar por el éxito beneficia principalmente a los bancos sin proporcionar los beneficios que los proponentes prometen. Concluye considerando el Pay For Success en relación con consideraciones económicas estructurales más amplias y los usos recientes de la educación pública para producir ganancias a corto plazo para los capitalistas.

Palabras-clave: Pay for Success; impacto social; Reforma Escolar de Chicago; Educación Neoliberal; Reforma de la Escuela Corporativa; Filantropía

\section{A promessa e as realidades de Pay for Success/Social Impact Bonds}

Resumo: Este artigo considera os argumentos dos proponentes para Pay for Success, também conhecidos como "Social Impact Bonds". Pay for Success permite aos bancos financiar serviços públicos com lucros potenciais ligados a métricas. Pagar pelo sucesso recebeu apoio federal através da Lei de Sucesso de Todos os Estudantes de 2016 e está prevista para 2020 para expandir nos EUA para um trilhão de dólares. À medida que os distritos escolares, as cidades e os estados enfrentam crises de dívida e orçamento, Pay for Success foi defendido por filantropos, empresas de consultoria corporativa, políticos e bancos de investimento com base em melhorar a prestação de contas, redução de custos, transferência de riscos e disciplina de mercado. Com sua história pioneira na educação neoliberal, Chicago fez uma experiência inicial em Pay for Success. Este artigo fornece uma análise conceitual dos principais pressupostos subjacentes e ideologias do Pay for Success. Ele examina as reivindicações de defensores e críticos e ilumina as motivações financeiras e ideológicas que animam Pay for Success. O artigo afirma que o Pay for Success beneficia principalmente os bancos sem beneficiar dos benefícios que os proponentes prometem. Conclui considerando Pay for Success em relação a considerações econômicas estruturais mais amplas e os recentes usos da educação pública para produzir lucro a curto prazo para os capitalistas.

Palavras-chave: Pay For Success; Impacto Social; Reforma Escolar de Chicago; Educação Neoliberal; Reforma Escolar Corporativa; Filantropia 


\section{The Promise and Realities of Pay for Success / Social Impact Bonds}

As Rahm Emanuel campaigned for his first term as Chicago Mayor in 2010, he stood to inherit a massive debt from his predecessor Richard J. Daley. Daley left office with unfunded pension liabilities, an indebted Chicago Public Schools (CPS), and a deeply indebted city in a deeply indebted state. With a penchant for neoliberal privatization schemes that included efforts to privatize airports, highways, and schools, Daley left city hall after privatizing all of the parking spaces in Chicago - selling them off to an investment bank. Daley promised that the fiscal woes of the city would be solved, but the $\$ 7$ billion one-time payout was gone within a year of the deal, leaving the city with one less resource for generating revenue. Daley's education program, Renaissance 2010, bore a striking resemblance to the parking fiasco, with the Commercial Club of Chicago orchestrating the closure of waves of public schools while it promoted the creation of charter schools. For decades, Daley had presided over the stripping of public school resources from neighborhoods through the use of Tax Increment Financing slush funds. These TIFs capture local tax revenue and redirect public tax money that would otherwise have gone to fund schools and put them into funds to subsidize private businesses.

Emanuel was committed to neoliberal privatization and immediately sought to privatize waste collection, recycling, and school janitorial services while keeping intact the parking meter privatization, and went on an aggressive public school privatization sweep that included increasing school closures and chartering begun by Daley (Lipman, 2014; Lipman, 2004; Perlstein, 2015; Saltman, 2007). The closure of 50 elementary schools stripped $\$ 67$ million in funding from the public schools while giving $\$ 62$ million to charter school operators (Perlstein, 2015).

A number of other educational privatization schemes were launched that received far less attention. For example, as those 50 elementary schools on the mostly poor and mostly African American and Latino/a west and south sides of the city were closed, often on the pretext of underutilization, Emanuel arranged to have part of Lincoln Elementary School in the rich White neighborhood of Lincoln Park move into the new state of the art Education building smart classrooms at private DePaul University. I taught teacher education candidates at night in these classrooms that featured new built-in educational technology, wifi, and smart boards. The DePaul education faculty had been working for decades out of an ill-equipped nuclear fallout shelter concrete bunker with few windows. While hundreds of thousands of dollars went from CPS to the private university to assure that these privileged children had the best facilities and were subsidized to ensure small class sizes, these children's schools were not targeted for closures and chartering like the schools of the west and south sides. The Lincoln Park children stayed at the university until their own elementary school was renovated. These practices made abundantly clear whose children deserved to receive investment and support for their public school.

When Emanuel took office in 2011, he promised to address the fiscal crisis of the Chicago Public Schools with an innovative financing approach that would allow him to expand educational services without raising taxes or issuing bonds. This turned out to be a scheme called Pay for Success or Social Impact Bonds (henceforth I will refer to these programs as Pay for Success). Pay for Success is significant not only in the context of Chicago school reform and its trailblazing tendency to aggressively embrace privatization, corporate models of management and reform, and neoliberal language and logic. Pay for Success is also significant for being nationally and internationally promoted as a solution to certain intractable financial and political problems facing public education. While Pay for Success is only at its early stages in the United States, the Rockefeller Foundation and Merrill Lynch estimate that by 2020, market size for impact investing will reach between $\$ 400$ billion to $\$ 1$ trillion (Quinton, 2015). The Every Student Succeeds Act of 
2016, the latest iteration of the Elementary and Secondary Education Act of 1965, directs federal dollars to incentivize these for profit educational endeavors significantly legitimizing and institutionalizing them. In addition, as Donald Trump's nomination for Secretary of Education Betsey Devos makes clear, the central educational priority of the new administration will be to aggressively expand the neoliberal dictates of privatization and defunding of public services. Pay for Success is, a more than anything, a privatization scheme dressed as innovation, accountability, and corporate social responsibility. It is thoroughly consistent with the more direct neoliberal privatization efforts now under way for vouchers, for profit charters, scholarship tax credits, and other forms of for profit contracting.

In what follows here, I provide a conceptual analysis of the underlying assumptions and ideologies of Pay for Success. I examine the claims of proponents and critics and shed light on the financial and ideological motivations animating Pay for Success. I begin by providing a brief history of Pay for Success and the arguments in support of it, showing the extent to which Pay for Success is neither innovative nor necessary but is rather a technique for rich investors to skim money out of public service provision, a hijacking of public governance, and misrepresentation of the corporate fleecing of the public sector as "corporate social responsibility." I address proponents' arguments that Pay for Success provides market discipline, cost savings, accountability, risk transfer, and corporate social responsibility. I conclude by situating Pay for Success in terms of the broader economic and cultural context that makes such schemes possible. A crucial question of this last section is: If Pay for Success does not address the needs that are alleged by proponents, including accountability, innovation, political will or risk transfer, then what needs or whose needs does it serve? I argue that it serves the needs of capital accumulation at a moment when capital is seeking new and untapped parts of the public sector for pillage. It also serves to symbolically recast such corporate pillage as generosity, care, and responsibility. I conclude with lessons that Chicagoans and others can learn about such "innovative financing" schemes.

\section{Pay For Success: Its Origins and Proponents' Claims}

Imported into the US from the UK around 2010, Pay for Success began as Social Impact Bonds, promoted by the leading consultancy advocate of neoliberal education McKinsey Consulting, the neoliberal think tank Center for American Progress founded by former Clinton Chief of Staff and Democratic Party leader John Podesta (who also lead Obama's transition), and the Rockefeller Foundation. Pay for Success expansion is now the central agenda of the Rockefeller Foundation. Shortly before championing Pay for Success for Chicago, Rahm Emanuel served as Obama's Chief of Staff, having had a long career as a hard-driving Democratic congressman and political fundraiser and also an investment banker. Daley brought Emanuel up through the Chicago democratic machine. Certain other key figures lobbied to expand the use of Pay for Success. Most notably, Jeffrey Liebman went from Obama's Office of Management and Budget to a large center at Harvard, the Government Performance Lab in the Kennedy School of Government dedicated to expanding Pay for Success. Liebman is a leader of the Center for American Progress and was a key economic advisor to Obama in his 2008 campaign. Other key influencers of Pay for Success include The Rockefeller Foundation and Third Sector Capital.

The prime financial beneficiaries of Pay for Success, who also happen to promote its social value, are the investment banks that invest in projects and, should the metrics pan out, stand to make back their money plus profit. Goldman Sachs, J.P. Morgan, Bank of America, and Merrill Lynch have been investing. Other financial beneficiaries include the lawyers who structure these complicated arrangements and the non-profit organizations that do as well. 
Proponents promote Pay for Success as an innovative financing technique that brings together social service providers with private funders and non-profit organizations committed to expanding social service provision. In theory, Pay for Success expands accountability because programs are independently evaluated for their success and the government only pays the funder (the bank) if the program meets the metrics. If the program exceeds the metrics, then the investor can receive bonus money. In other words, the social program becomes more expensive for the public institution the better the metrics that display its success. Pay for Success projects are arranged between governments, banks, non-profit philanthropies, and evaluating agents. Often academic actors like the Government Performance Lab at Harvard are involved in facilitating the deals.

The first Chicago Pay for Success project involved Goldman Sachs spending \$17 million to expand an early childhood education program that had long been operating successfully (Sanchez, 2016a, 2016b). The successful metrics allow Goldman Sachs to be paid more than $\$ 30$ million for funding the expansion of the public service thereby roughly doubling its investment. Despite proponents' claims of “innovation” in program development, Chicago's Pay for Success early childhood project, as the commissioned evaluation report makes clear, had been operating since 2002 and received positive evaluations. Early childhood education interventions such as the Child Parent Center model have been measured and found to have positive effects on future academic performance since 1967 (Gaylor, 16). Pay for Success implementation in Chicago has been based in the same central promises found in Pay for Success elsewhere: that it would cut costs, increase accountability, encourage innovation, and shift risk from the public to the private sectors. In the sections on the myths of Pay for Success below I address each of these premises.

Neoliberal politicians like Rahm Emanuel love Pay for Success because it allows them to claim they are expanding public services through "innovative finance" without raising taxes even as the inflated costs of the projects get backloaded onto the public. Banks like Goldman Sachs love Pay for Success because as Chicago illustrates they earn large profits and do so while gaming both the selection of programs and the evaluation of the success of projects and while getting philanthropies like Bloomberg and Rockefeller to insure their profits. Banks with sordid records of white collar crime also love Pay for Success because they can make money while improving their public image. Neoliberal philanthropies also love Pay for Success because it is consistent with a rightist ideological perspective in which the only way to fund the social state is through the profit seeking activities of the private sector.

Advocates contend that the value of a Pay for Success program is allegedly: 1) it creates a market incentive for a bank or investor to fund a social program like Chicago's preschool when allegedly there is no political will to support the expansion of public services; 2) it shifts risk away from the public and onto the private sector while retaining only the potential social benefit for the public; 3) by injecting "market discipline" into the bureaucratically encumbered public sector, Pay for Success will make the public sector "accountable" through investment in "what works" and it will avoid funding public programs for which the public has "little to show," as Liebman and Third Sector Capital Partners are fond of suggesting (Wallace, 2014). The value of any public spending in this view must be measurable through quantitative metrics to be of social value; 4) it consequently saves money by not funding programs that cannot be shown to be effective; 5) and lastly, it mobilizes supposedly beneficent corporations, banks, powerful non-profit companies, and philanthropic foundations to save the poor, the powerless, and the public from themselves. Here, Goldman Sachs frames its profit seeking activities as corporate social responsibility, charity, and good works that define its image in the public mind (Goldman Sachs, 2014).

In fact, all five of these positions that advocates claim explicitly or implicitly to support the expansion of Pay for Success are baseless, as evidenced by accounts of actually existing programs in 
Chicago, Massachusetts, New York, and elsewhere. Furthermore, the basic premises of Pay for Success are contradicted by the actions and statements of its key actors and proponents such as banks, politicians, and non-profits. In what follows here I examine more closely these proponents' specific claims. While this article gives more focus to Chicago than other sites where Pay for Success projects have been done, I do not do an original empirical analysis of the Chicago Pay for Success projects. Rather I draw on the empirical studies, advocacy literature that have been done of Pay for Success and offer an analysis of the underlying assumptions and ideologies that have been used to justify Pay for Success everywhere.

Existing scholarship thus far on Pay for Success lacks an examination of the key assumptions of the policy actors behind it. This article seeks to address that absence. What is at stake is not merely whether or not Pay for Success "works," but rather what Pay for Success "works to do." To understand what it works to do requires both conceptual analysis of the justifications offered by proponents and situating the policy in relation to broader economic, political, and ideological trends and struggles. It is for this reason that Chicago is particularly important to consider in relation to Pay for Success as it has been at the forefront of the neoliberal restructuring of the public sphere for decades both in terms of policy and in terms of the intellectual origins of neoliberal economic doctrine and ideology. Such restructuring represents a racialized project of ruling class efforts to take public wealth and assert private control over public governance (Lipman, 2014; Robinson, 2014; Saltman, 2007). As I discuss below, Pay for Success works to privatize public services and shift resources from the public to the private spheres. Empirical data collection as to the efficacy of the specific policy presumes the legitimacy of a policy that as I argue below needs to be comprehended as illegitimate in terms of its framing assumptions. To put this methodological question in the bluntest form, restricting adequate examination of underlying theoretical assumptions and instead focusing only on questions of efficacy one would have no way of considering what is wrong, for example, with a project to heat a city apartment with a thermonuclear blast. One could measure to what extent the nuclear explosion warmed the air and come to some compelling conclusions of it as a heating device. The restriction of debates to efficacy leaves no way to ask the most crucial questions as to what a policy ultimately aims to achieve and how it is socially meaningful in relation to broader social realities and struggles.

If, as I argue here, the assumptions behind the policy and practices are unfounded then Pay for Success is likely motivated by something other than what proponents allege. To grasp what is motivating it requires comprehending the policy in terms of the broader economic, political, and cultural contexts in which extant struggles over the restructuring of education play out. The meaning of empirical and assertional claims about Pay for Success efficacy depend for their intelligibility on the underlying theoretical assumptions about the policy, about the problem it seeks to remedy and about the solutions. Hence, this study of the key claims and assumptions made by proponents should be seen as a necessary precursor for future evaluation of Pay for Success. However, as this article makes clear, efficacy studies that ignore the framing assumptions of Pay for Success uncritically accept and affirm these assumptions thereby colluding with the growing trends to defund, dismantle, and privatize public education while eroding its public and democratic roles. Considering the massive amount of public money at stake, the massive shift in governance from public to private, and the broader implications of public school privatization there are enormous stakes in failing to examine precisely what is being assumed by the leading proponents of Pay for Success. As I discuss below, Pay for Success depends for its appearance of legitimacy on the guise of numerical accountability that is part of a broader pattern within neoliberal educational restructuring. 


\section{The Myths of Pay for Success in Chicago and Beyond}

\section{Market Incentives, Political Will, Innovative Programs}

Repeating a longstanding neoliberal mantra of private sector efficiency and public sector bloat, advocates of Pay for Success claim that the programs are necessary because they inject a healthy dose of market discipline into the bureaucratically encumbered and unaccountable public sphere. According to the leading proponent of Pay for Success, Jeffrey Liebman of the Government Performance Lab at Harvard University, private sector finance produces this market discipline because governments do not monitor and measure the services provided by contractors. Liebman says, "(Government) Programs that don't produce results continue to be financed year after year, something that would not happen in the business world" (Overland, 2011). This is an odd claim from one of Obama's leading economic advisors at the time that Obama was sworn in as President and proceeded to have the public sector bail out the private sector. The 2008 financial bailout of the banks by the U.S. federal government represents a repudiation of the neoliberal logic of the natural discipline of markets and of deregulation. The private sector including banks, insurance companies, and the automotive industry needed the public sector to step in and save unprofitable businesses and businesses that had invested in the deregulated mortgage backed securities markets. More broadly, some of the largest sectors of the economy such as defense, agriculture, and entertainment rely on massive public sector subsidies to function. Specifically, the financial crisis and consequent recession was a result first of neoliberal bank deregulation and a faith in markets to regulate themselves but also it demonstrated the illegal activity, fraud, and lies of the same banks that now seek profit through Pay for Success including Goldman Sachs, Bank of America, Merrill Lynch, and J.P. Morgan.

Pay for Success proponents claim that the financing scheme is necessary because there would otherwise not be the political will to do projects such as early childhood education in Chicago for a couple of thousand children or recidivism reduction programs in Massachusetts. Third Sector Capital Partners, a non-profit that relies on Pay for Success expansion as a cornerstone of its business, claims that Americans do not support state spending and hence Pay for Success is necessary (Von Glhn \& Whistler, 2011). In fact, Gallup show that $75 \%$ of Americans favor expanded public spending on infrastructure (Newport, 2016a) and 58\% support replacing the Affordable Care Act with a universal federal healthcare system (Newport, 2016b). Indeed, as longstanding studies and more recently the Bernie Sanders presidential campaign of 2016 indicated, a large percentage of Americans support a range of increased spending on progressive social programs. Specifically, in Chicago the early childhood education program was popular with parents and early childhood public daycare is in extremely high demand yet has been in short supply. This short supply does not justify Pay for Success programs but rather indicts the pattern of social disinvestment in caregiving state functions. These disinvestments also represent a form of wealth transfer as the onus to fund the programs is lifted from the wealthiest citizens.

A mantra found in the literature that advocates Pay for Success is that it "allow $[\mathrm{s}]$ the government to avoid paying for programs that don't make a difference" (Overland, 2011). For working class and poor Chicagoans, many of whom are working two and three low paying jobs, the cost of private early childcare and education is a major financial burden. The fact that early childcare and education are vital economic needs for working parents raises a question about whose political will is in question when Pay for Success proponents claim that the only way to provide early child educational services is with the involvement of banks, and without banks it should not be provided. The parents and community members are not the ones who lack the political will. Political and financial elites do not want CPS to pay for other people's children; yet, they are happy to have CPS 
pay for their children in the well-funded neighborhood schools of upper professional class and ruling class and predominantly White Lincoln Park, Roscoe Village, and the Loop.

The Chicago early childhood Pay for Success project had already been operating since 2002 with great success and continued demand from parents and community (Gaylor, 2016). The mayor's introduction of banks to finance and then profit from this ongoing project says nothing about the parental and community will to support the program. However, it says a lot about the will of the mayor and his business backers to make public services lucrative to those who already have capital.

\section{Transfer of Risk}

The elaborate involvement of banks, lawyers, profits, and non-profit coordinating companies appears more than superfluous when one takes a closer look at what is actually being done in Chicago through the expansion of pre-K to 2,600 Chicago Public School children. Emanuel's office lists six schools on the west and south sides and reports, "CPS and its teachers will manage the expanded program in these schools for the current academic year and expand to additional schools in future years" (Mayor's Press Office, 2014). If the program simply expands existing CPS programs with already employed teachers and administrators, then the potentially significantly higher cost of using the Pay for Success makes little sense. In other words, why not just expand the existing successful services such as the parent-child centers that had been successful in Chicago since 2002 (Gaylor, 2016)? According to the mayor's office, the risk is worth it because Pay for Success "is structured to insure that its lenders, the Goldman Sachs Social Impact Bond Fund and Northern Trust as senior lenders, and the J.B. and M.K. Pritzker Family Foundation as a subordinate lender, are only repaid if students realize positive academic results" (Mayor's Office, 2014). However, critics of Pay for Success point out that in reality there is little risk for investors of losing that $\$ 17$ million because the investors select already proven projects such as those in Chicago (Sanchez, 2016). Indeed, they are more likely to make the millions more in profit as in the $\$ 30$ million that Goldman was paid back (Sanchez, 2016). As Melissa Sanchez of Catalyst Chicago points out, investors make not only profits but additionally receive positive public relations, good will, and image boosting (Sanchez). This is not a small matter for a bank such as Goldman Sachs that was in the center of the sub-prime mortgage crisis and was found to have committed both potentially illegal and unethical investment practices.

Risk is also mitigated for the banks by philanthropies such as Rockefeller or Bloomberg that guarantee repayment of the money the banks invest (Quinton, 2013). Even the proponents admit that Pay for Success is "not a panacea" as banks are not really willing to take risks and consequently they are only willing to consider about 20\% of service providers (Overland, 2011). The attractive service providers are ones with established track records that all but guarantee success. Pay for Success cannot be justified as an innovative scheme that injects the risk taking of the market into the public sector.

Economist David Macdonald (2013) points out the extent to which the promise of risk transfer is in fact a lie. Macdonald explains that Pay for Success is not experimental. He argues that a bank such as Goldman Sachs is never going to put up $\$ 5$ million with a 50\% risk of losing their money, and so it will invest only in proven projects. Moreover, even if Goldman were to take a risk and the metrics did not pan out in its favor, there's no way the government will refuse to pay Goldman Sachs back the full $\$ 5$ million. Why? Because if Goldman Sachs loses $\$ 5$ million or any part of it, it's not going to come back next year, and neither are any of the other bankers and private investors. (Macdonald, 2013, 37) 
Yet, even with the risk to bank profits eliminated by highly selective program selection, underwriting by philanthropies, and the government's desire to keep the bank coming back, as the Chicago example highlights, even if the leveraged Chicago Public Schools go bankrupt as the Republican Investment Banker Governor of Illinois Bruce Rauner seems intent to cause banks such as Goldman Sachs are first in line as creditors as the pieces of the system are sold off (Joravsky, 2016). So rather than a system that injects the risk taking of markets into the public sector, Pay for Success injects capital drainage into successful programs while assuring minimal risk only for the profiteers. As Macdonald (2013) writes, the inversion of risk represents a disturbing change in who government serves:

People pay their taxes (and expect corporations to do so as well) in part because they want the government to deliver good services to the people who need them. But social impact bonds direct tax dollars to bank profits instead of to people in need. This dramatically changes who is being served by the government: from those who need a helping hand to affluent investors who need no government help at all.

(Macdonald, 2013)

\section{Accountability}

Another claim that proponents make as to the efficacy of Pay for Success programs is that these programs are more accountable than the public sector because programs are measured independently. As the principles of Third Sector Capital write, "Outcomes need to be tangible and measurable, such as reduced recidivism rates and lower utilization of foster care placement. The analyses of fiscal savings need to be demonstrated in quantifiable numbers, such as a reduction in special education dollars, lower Medicare payouts and lower juvenile justice expenditures" (Von Glahn \& Whistler, 2011, p. 22).

Yet critics of Pay for Success have raised issues about who is making the decisions about measurement and how benchmarks have been decided (Overland, 2011, 5). A basic problem with this argument for accountability through measurable outcomes is that, in practice, as a juvenile justice caseworker involved in a recidivism reduction Massachusetts Pay for Success project explained to me, s/he received constant phone calls from an investment bank encouraging him/her to have the metrics turn out in the favor of the bank so that the bank would earn the maximum amount possible through the bond. Indeed, what I heard directly from a participant in a Pay for Success was a general concern of Jon Pratt, head of the Minnesota Council of Nonprofits. Pratt (Wallace, 2014) stated, "You're definitely creating incentives that would be considered corruption

pressures." Pratt's point is that by having allegedly independent measurement tied to the possibility of profit or loss, a not-so-independent incentive is created to game the outcomes or cheat.

Such "corruption pressures" in neoliberal education reform have had a high profile as high stakes standardized testing threatened to defund school districts, schools, and classrooms if test scores did not rise. Administrators and teachers, deeply concerned that poor students would lose desperately needed resources, found that the ethical action would be to cheat rather that participate in sanctifying the denial of resources to those most in need. Similarly, when the largest for profit educational management company, Edison Schools, was expanding in the 1990s and 2000s, their increased growth depended upon continually raising more investor capital. The for-profit education company could only acquire capital by showing prospective investors increasingly rising test scores (Saltman, 2005). As a consequence, numerous test scandals erupted and massive institutional pressure was placed on administrators and teachers to show raised test scores no matter what.

Other critics raise practical concerns with Pay for Success, including concern that organizational capacity of a service provider can be temporarily built up by a contract but "not build 
the organizations' capacity to support that growth" (Wallace, p. 4). As well, critics point to how time-consuming these agreements are to create (Wallace, p. 4). Contracts are so convoluted and complicated that what normally would take a month to do takes two years and with financial arrangements so complicated that a university professor in financial management "still needed help understanding the financing" (Farmer, 2015).

In Chicago's Pay for Success early childhood project, as the commissioned evaluation report makes clear, not only had this particular project received positive evaluations since 2002, but early childhood education interventions such as this Child Parent Center model have been measured and found to have positive effects on future academic performance since 1967 (Gaylor, 16). Unsurprisingly, that is, early childhood learning initiatives have been known to result in measurable improvements in student performance in subsequent academic years. These facts raise obvious questions as to Pay for Success advocates' claims that private bank financing is needed to assure measurable accountability.

An additional problem with accountability being understood strictly through numerically quantifiable measurement is that the problems of positivist ideology are brought into areas of educational service that are not necessary ideally measurable in quantitative terms. Positivist ideology treats knowledge and truth as a collection of facts and radically devalues examination of the theoretical assumptions behind claims to truth (Giroux, 1983). Knowledge in this view disregards both the relationship between learning and the interpretive practices and perspectives of subjects as well as the relationship between learning and the broader social world (Giroux, 1983). As Pay for Success receive that $\$ 400$ billion to $\$ 1$ trillion, they will be used for a wider array of educational services including many areas of schooling in which learning is interpretive and involves judgment, criticism, and analysis. Not necessarily always quantifiable, the development of such interpretive capacities do not always appear immediately but progress over time. The message from the leaders of Pay for Success is that the government spends billions of dollars on public services that are not measured and hence has "little to show for it" (Wallace, 2). Implicit here is an assumption that that which cannot be immediately measured quantifiably also cannot be justified as a public expense. This presumes that the kinds of subjects that are less quantifiably measured such as the humanities or abstract sciences are less valuable and that funding in the future ought only to follow that which can be quantified.

An assumption as to value being found primarily in that which can be displayed represents a corporate managerial logic that is consistent with the radical expansion of a private sector style bureaucracy in public schooling that I have referred to as the "New Market Bureaucracy" (Saltman, 2012). Neoliberal privatization initiatives such as charters, vouchers, scholarship tax credits, and database tracking projects have been promoted since the early 1990s based on the promise of debureaucratizing the public sector (Chubb \& Moe, 1990). In fact, since the 90's a massive new bureaucracy has been installed comprised of venture philanthropies and national, state, and local organizations funded and promoted by them dedicated to treating the public schools as private industry and fostering privatization, corporate culture, and managerialism. Within this new market bureaucracy, numerically quantifiable displays of efficacy, which Mark Fisher has described as "market Stalinism," trump actual production of value in an enterprise (Fisher, 2009; Saltman, 2012). In this context, the game of "juking the stats" to show ever increasing numerical progress displaces thoughtful consideration and deliberation as to the meaning and value of what is being measured. The testing craze of the past decade and a half mistakenly suggests that learning and raised test scores are equivalent even as meaningful classroom pedagogy is displaced for test-preparation and entire socially-valuable bodies of knowledge such as literature and history, music and art are sacrificed on the alter of measurable efficacy. The point not to be missed here is that this is not a 
debate between science and math on the one hand versus, on the other, the arts and humanities. At stake here is that under the guise of disinterested objectivity, neutrality, and universal value, particular values and interests are being normalized in any given Pay for Success project.

The denial of interests and values renders the measurement fetish of accountability pseudoscience or scientism. For example, Goldman Sachs, J.P. Morgan, and Bank of America have all been seeking profit in Pay for Success. Each bank has paid the U.S. Department of Justice multi-billion dollar settlements for not prosecuting them for lying about the risks of subprime mortgage investments and defrauding investors in the run up to the 2008 subprime crisis and great recession (Shen, 2016). In 2011 confessed financial fraudster Goldman Sachs sought 22\% profit on its investment of \$9.6 million in a Riker's Island Pay for Success project teaching moral reasoning to juvenile inmates (Quinton, 2013). The efficacy of the project was to be measured by reducing recidivism. Shortly after lying and breaking the law for profit, Goldman Sachs received a contract from New York City's billionaire Mayor Michael Bloomberg. Bloomberg's own philanthropy insured the Goldman Sachs investment so that, should the metrics not pan out, the bank would not lose money. While this particular Pay for Success project did not achieve the metrics (Quinton, 2013), the value of the metrics themselves as an arbiter of the value of the project are profoundly suspect in that they shut down some of the most crucial questions that need to be asked of such a project, such as: Why would a company responsible for tanking the economy through fraud be hired to teach moral reasoning to youth? Why are the youth incarcerated in the first place and what class and race position do they come from? Why did none of the leaders of Goldman Sachs or the other banks who broke the law in the financial crisis spend a day in prison and what class and race positions do they come from? What are the broader structural and systemic patterns and power relations that produce these different lived realities of legal accountability for some and no accountability for others like the ways that a racialized class hierarchy is reproduced through mass incarceration, the finance industry, and the educational system? Who is authorized to develop the metrics, what is their expertise, what are their interests, and how do they assess the rules they set in place? To whom are those legislating the accountability measurements accountable? The scientism of metrics obscures these kinds of questions. Accountability should be a part of educational projects but not through restricted metrics that conceal the broader politics informing the project. Rather, accountability should be in a form in which knowledge is comprehended in relation to how subjectivity is formed through broader social forces and in ways in which learning can form the basis for collective action to expand egalitarian and just social relations.

\section{Cost Savings}

A central argument of Pay for Success proponents is that they save money by only funding successful programs. However, as the prior sections suggest, if in fact evaluation is not independent and only already successful programs are being selected, and governments have incentives to continue contracting, and there are "corruption pressures," and tax sheltered non-profit philanthropies insure the profits of private banks, then the alleged "market discipline" through competition cannot work. Yet, there is additional evidence that Pay for Success adds costs rather than cutting them.

Pay for Success introduces large expenses to fund extensive legal services to handle those convoluted and complicated contracts that take years instead of months (Sanchez, 2014). Additionally, third party project managers and evaluators add costs to the services (Sanchez 2014). If the metrics pan out for the investors, then they can earn more than double the money that they put up for the service (Sanchez, 2014, p. 2). The intensely time-consuming and convoluted deals cost more money for administration, and this cuts into the spending on the service itself (Wallace, 2014). 
The Department of Legislative Services in Maryland studied Social Impact Bonds for recidivism reduction programs and found no savings (Wallace, 2014, p. 5). For prisons or schools with fixed costs such as physical sites, saving in per inmate or student cost is not significant because it does not reduce the fixed costs (Wallace, 2014, p. 5).

In West Chicago, one of the billionaire heir's to the Hyatt hotel fortune, J.B. Pritzker, whose investment firm worked with Goldman Sachs on the Chicago early childhood Pay for Success project, cut the ribbon at an early childhood center and stated that such projects must be good investments to be successful (Wallace, 2014, 6). Pritzker's statement aligns with a trend that has intensified since the advent of venture philanthropy reimagined philanthropy as being similar to business (Saltman, 2010). Venture philanthropies hijack public governance, install corporate models and managerialism for public services, and promote public sector privatization by steering the use of public money towards the private sector (Saltman, 2010). Venture philanthropies generally give money and the giving results in a tax break for the corporation or rich donor that gives to the nonprofit. However, most venture philanthropies do not actually seek to get the money back, let alone with profit. Social Impact Bonds (aka Pay for Success), according to David Macdonald, are not philanthropy; they are, rather, "anti-philanthropy.”(Macdonald, 2013) They are profit-seeking activity masquerading as philanthropy. Some venture philanthropy has a similar effect, such as when Gates and Microsoft privatize public education by the initiatives of the Gates Foundation for privatization schemes, technology dependency and so on. However, not even venture philanthropy is explicitly organized as a for profit business. Pay for Success is similar to the Chan Zuckerberg Initiative launched in 2015 in which the "philanthropy" is actually a limited liability corporation that financially invests in other projects. As Macdonald suggests, why not cut out the "middleman"? That is, why not cut out the banks seeking profit and the third parties and lawyers facilitating the deals. In this way the problem with Pay for Success is similar to the problem with Chicago's mixed income, mixed finance real estate developments that replaced the10 large public housing projects in the city. Promoted as a beneficial public private partnership the privatized housing reduced the total number of public housing units, dispossessed community residents, and gentrified sections of the city long coveted by real estate developers. Yet, they also introduced enormous per unit costs into the process by adding in legal and private developer fees and costs resulting in each unit costing the government much more than had the government simply directly provided the units (Saltman, 2007).

Finally, a cost problem with Pay for Success is that, as critics contend, with private sector lenders involved, interest rates will tend to be higher than with public sector bond issuance. House Appropriations Committee Chair Representative Ross Hunter blocked a federal Social Impact Bond bill. He said, "As a private investor, what kind of interest rate are you going to ask for? Eleven percent? Nine percent? By contrast, interest rates on revenue bonds can be as low as $4 \%$. If early learning is a good idea, I can issue [government-backed revenue] bonds to pay for it" (Hoback, 2015). In Chicago, Goldman Sachs' could more than double their initial investment of $\$ 16.6$ million (Sanchez, 2016) as the metrics determine that Goldman receives the maximum amount from the city under the agreement. This is a much higher total cost to the public to provide the service to 2600 children than what a bond issuance would be.

\section{Corporate Social Responsibility}

In order for banks, corporate foundations, and venture philanthropies to claim that Pay for

Success represents the good will of these actors, they must represent the drainage of wealth from the public sector and transfer of risk onto the public sector as public sector support and care. However, they must also position these private accumulation projects as necessary, inevitable, and without 
alternative. This is why proponents repeat the private sector language about the "hopelessly bureaucratic public sector" needing "market discipline," private sector "cost savings," "accountability," "financial innovation," and "risk reduction" despite evidence and reason to the contrary(Overland, 2011; Quinton, 2013). The private sector project of Pay for Success is not merely one that involves the private capture of public wealth. It also involves the public reframing of symbolic meanings that make such wealth capture possible, remaking common sense in ways that suggest that only the rich can promote just social change by pursuing their financial interests. Such ideologies suggest that the very private forces responsible for draining and weakening the public are in fact saviors for the public, that there is no alternative to markets in every social realm, that public citizens are nothing more than economic actors, and that these projects are apolitical rather than representing the interests and perspectives of capitalists over workers and most citizens. Non-profits such as the Center for American Progress, the Rockefeller Foundation, and the richest and most prestigious elite university Harvard (with its Government Performance Lab housed in the Kennedy School of Government) are among the loudest boosters of Pay for Success. The ideological work that these organizations do shapes public perceptions about the morality and public impact of private sector organizations like Goldman Sachs. In this sense, Pay for Success is a form of public relations for banks that the banks largely do not have to pay for. In fact, Pay for Success facilitates banks being paid by the public to promote this public relations bonanza. As with venture philanthropies, the public ends up not only financially subsidizing private banks but also subsidizing the loss of public control over public governance for public services. With venture philanthropies, the subsidy takes public revenues in the form of tax breaks for rich donors and corporations. With Pay for Success, the public pays a premium for services that could have been provided directly through the government and loses democratic governance control over the service.

\section{Conclusion: Situating Pay for Success/ Social Impact Bonds}

Pay for Success/Social Impact Bonds needs to be understood as part of a long legacy of neoliberal educational restructuring in Chicago, the United States, and globally. In Chicago this legacy has included aggressive public school defunding and closure followed by privatization in the form of chartering. These initiatives have resulted in intensified racial segregation, no improvement in traditional measures of student achievement, exacerbated inequalities in pay for teachers and administrators, the worsening of job security and work conditions for teachers through unionbusting. Neoliberal education has also promoted the expansion of corporate culture and managerialism in schools, and the expansion of repressive pedagogies that are at odds with the best traditions of public and critical education (Saltman, 2012). As Dorothy Shipps has detailed, there is more than a century of business led school reform in Chicago that produced the radically unequal state of public education (Shipps, 2006). The Commercial Club of Chicago, which represents the largest corporations in the city, has been able to steer educational policy with democratic machine mayors to enact a private sector view of schooling. In this view, public schooling is seen as vocational and is designed to make a low paid workforce or to simply contain the poorest youth (Lipman, 2004). A select number of elite and well-funded public schools have been maintained in the richest and whitest parts of the city. The use of tax increment financing districts to drain public taxes and funnel money to business has been a longstanding tactic to achieve a vision that is best for business. Working class and poor African Americans and Latino/as have been the primary victims of these class and race driven policies.

Pay for Success/ Social Impact Bonds appeal to banks for their capacity to generate profits from public tax money for education and other services. Like Tax Increment Financing zones they 
represent a form of economic redistribution from desperately needed public money for schoolchildren to business. They also appeal to banks who have gotten caught defrauding investors and that can now promote themselves as doing good works while turning a profit. Pay for Success also appeals to neoliberal politicians such as Mayor Emanuel who can claim they are doing "innovative finance" in the interest of taxpayers instead of raising taxes or issuing educational bonds. The reality is that Emanuel is just kicking the can down the road as Pay for Success does not solve the historical failure to adequately fund public education and other public services, just adding to the longstanding debt burden. In fact, because it costs more, Social Impact investing raises this debt burden while delaying it, thereby destabilizing the public system further. In this sense, Pay for Success is an elaborate form of public relations that makes a failure to address a public problem look like innovative action.

If Pay for Success does not achieve what proponents promise and does not solve the problems of public education, then what do they do? Like chartering and other forms of privatization, they appear to be a form of reform that does nothing to upset the longstanding relations of class and racial power and the longstanding use of the public schools to reproduce the tiered labor force. However, they also serve other financial functions.

U.S. cities such as Chicago have been since the 1970s deindustrialized and restructured through financialization and a consumer economy. The historical role of urban public schools in producing students with the skills, know-how, and ideological dispositions for the workforce has changed. In the industrial economy, business profit was largely generated through public schools by making long term investments in future workers and consumers. With the disappearance and off-shoring of unionized well-paying factory work, and the steady decline in real wages, increasingly urban public schools have served a warehousing role that keeps youth out of the labor market (Robinson, 2014). Since the late 1980s, urban public schools have been targeted as a revenue source for business and a place to invest the glut of capital that corporations and banks have accumulated by stagnating real wages paired with increases in worker productivity. This has resulted in a crisis of capital accumulation (Robinson, 2014). Public education has become a target for immediate short-term profit through a variety of contracting and privatization schemes. As in for profit prisons, for profit schools generate profits per pupil by getting public tax revenue but then cutting expenses. The business press and billionaire magnates, such as News Corp owner Rupert Murdoch, have not been shy about declaring public education as ripe for profit seeking, describing public education as private industry and likening education to the private defense, agriculture, and military sectors (Businessweek 2002). Pay for Success/Social Impact Bonds can be understood then not as philanthropy, not as innovative finance, and certainly not as caregiving activities from banks. Pay for Success/Social Impact Bonds ought to be understood as simply one of the latest efforts of the private sector to exploit and to pillage the public sector for profit at a historical moment of uncertain economic growth and a crisis of capital accumulation.

I have suggested here that Pay for Success is justified by proponents on five key problematic promises or myths: political will/market discipline, risk transfer, accountability, cost savings, and corporate social responsibility. The solution to the problem of Pay for Success is not more efficacy studies, debates about the metrics, or call for further research and experimentation. Such approaches affirm rather than question the myths that Pay for Success is premised on. Rather, Pay for Success needs to be recognized as a project that represents the financial interests of a small number of ruling class people to hold public service provision hostage to private sector profit taking. The opposite direction would call for public interest policy enactment that would create a firewall between philanthropic organizations such as Rockefeller Foundation, Bloomberg Philanthropies, and Third Sector Capital and the public uses of their money. Rather than allowing super rich individuals, 
investment banks and their tax sheltering foundations to hijack public governance, the public ought to be taking back control of the uses of public tax wealth. Such efforts to take back public control can involve grassroots campaigns for elected school boards, moves to link teachers and parents groups to broader social movements, and pedagogical projects within existing institutions that offer the intellectual tools for social analysis and action. As this goes to press somewhat veiled neoliberal privatization efforts represented by Pay for Success are being eclipsed in public discourse by an overt and muscular direct government effort to spearhead vouchers, for profit charter schooling, and scholarship tax credit "neo-vouchers" by the Trump administration. Those interested in defending public education as a part of the democratic public sphere ought to recognize that these "innovative" school finance projects all aim to evacuate the public purposes of public schooling as they radically transform public education into a private industry.

\section{References}

Chandler, D. (2015, October 22) Op-Ed: Social Impact Bonds: Selling off the Public Good in the Era of Neoliberalism. Retrieved from http:/ / www.truth-out.org/opinion/item/33353social-impact-bonds-selling-off-the-public-good-in-the-era-of-neoliberalism $>$

Chubb, J., \& Moe, T. (1990) Politics, Markets, and America's Schools. Washington, DC: Brookings Institution Press.

Donovan, D. (2013, April 25) \$500 Million Plan Would Reimburse Donors Who Start or Expand Programs that Work. Chronicle of Philanthropy, 25(11), 13-13.

Editorial Board. (2015 November 8). Editorial: The Promise and Risk of Social Impact Bonds. Chicago Tribune. Retrieved from http://www.chicagotribune.com/news/opinion/editorials/ct-social-impact-bond-illinoischicago-edit-20151106-story.html

Farmer, L. (2015 November 12). The Hidden Cost to 'Pay for Success. Governing. Retrieved from http://www.governing.com/topics/finance/gov-cost-pay-for-success-social-impactbonds.html.

Fisher, M. (2009). Capitalist Realism: Is There No Alternative. London: Zero Books.

Gaylor, E., Kutaka, T., Ferguson, K, Williamson, C., Wei, X., \& Spiker, D. (2016). Evaluation of Kindergarten Readiness in Five Child-Parent Centers: Report for 2014-15. Prepared for IFF Pay for Success I, LLC. Menlo Park, CA. SRI International.

Giroux, H. (1983). Theory and Resistance in Education: A Pedagogy for the Opposition. Westport, CT: Bergin \& Garvey.

Golden, M. (2014, October 10). How Pay-for-Success Funding Might Help Low-Income Students. Chronicle of Higher Education, 61(6), A22-A23.

Goldman Sachs. (2014) What is a Social Impact Bond? Retrieved from http://www.goldmansachs.com/our-thinking/pages/social-impact-bonds.html

Hoback, J. (2015 May). Private Money, Public Impact. State Legislatures, 26-29.

How Social-Impact Bonds Work. (2011, February 24). Chronicle of Philanthropy, $23(7), 7$.

Jonas, C., \& Grossman, J. (2014, February) Pay for Success Leading Change in Results-Based Contracting. Policy \& Practice [Third Sector Capital Partners Newsletter], 13-34.

Joravsky, B. (2016, February 11.) Rahm's Latest Wall Street Bond Deal is a Bad Deal for the City. The Chicago Reader. Retrieved http://www.chicagoreader.com/Bleader/archives/2016/02/11/rahms-latest-wall-streetbond-deal-is-a-bad-deal-for-the-city

Lipman, P. (2014). The Political Economy of Urban Education. New York: Routledge. 
Lipman, P. (2004). High Stakes Education New York: Routledge.

Macdonald, D. (2013, February) Anti-Philanthropy: Social Impact Bond the Worst Way to Fund Social Programs. CCPA Monitor, 37.

Mayor's Press Office. (2014, October 7). Mayor Emanuel Announces Expansion of Pre-K to More than 2,600 Chicago Public School Children. Retrieved from http://www.cityofchicago.org/city/en/depts/mayor/press_room/press_releases/2014/oct /mayor-emanuel-announces-expansion-of-pre-k-to-more-than-2-600-ch.html

Newport, F. (2016, March 21). Americans Say Yes to Spending More on VA Infrastructure. Gallup. Retrieved from http://www.gallup.com/poll/190136/americans-say-yes-spendinginfrastructure.aspx?g source $=$ federal $\% 20$ spending $\& g$ medium $=$ search $\& g$ campaign $=$ tiles

Newport, F. (2016, May 16). Majority in U.S. Support Fed-Funded Healthcare System. Gallup. Retrieved from http://www.gallup.com/poll/191504/majority-support-idea-fed-fundedhealthcare-system.aspx?g source $=$ Politics\&g medium $=$ newsfeed\&g campaign $=$ tiles

Perlstein, R. (2015, January 21). How to Sell Off a City. In These Times. Retrieved from http://www.inthesetimes.com

Overland, M. (2011, February 24). Paying for Results: A New Approach to Government Aid. Chronicle of Philanthropy, 23(7), 9.

Quinton, S. (2013, May 10). How Goldman Sachs Can Help Save the Safety Net. National Journal, 1.

Robinson, W. I. (2014) Global Capitalism and the Crisis of Humanity. Cambridge: Cambridge University Press.

Saltman, K. (2007). Capitaliæing on Disaster: Taking and Breaking Public Schools. New York: Routledge.

Saltman, K. (2010). The Gift of Education: Public Education and Venture Philanthropy. New York: Palgrave Macmillan.

Saltman, K. (2012). The Failure of Corporate School Reform. New York: Routledge.

Sanchez, M. (2016a, May 16). Investors Earn Max Initial Payment from Chicago's 'Social Impact Bond'. Catalyst Chicago. Retrieved from catalystchicago.org

Sanchez, M. (2016b, May 16). Child-Parent Centers Boast Strong Results for Kids, Investors. Catalyst Chicago.

Sanchez, M. (2014, November 3) For the Record: Paying for Preschool with Social Impact Bonds Catalyst Chicago. Retrieved from catalystchicago.org

Shen, L. (2016, April 11). Goldman Sachs Finally Admits It Defrauded Investors During the Financial Crisis. Fortune. Retrieved from http://fortune.com/2016/04/11/goldman-sachsdoj-settlement/

Shipps, D. (2006). School Reform Corporate Style, Chicago 1880-2000. Lawrence, KS: University Press of Kansas.

Von Glahn, D., \& Whistler, C. (2011, June). Pay for Success Programs: An Introduction Policy \& Practice (Third Sector Capital Partners Newsletter).

Wallace, N. (2014, July 17). With a Few Pay-for-Success Plans Under Way, the idea is Gaining Currency and Criticism. Chronicle of Philanthropy, 26(15), 1-23.

York, P. (2011, May 19). 'Pay for Success' Idea Could Fail Nonprofits. Chronicle of Philanthropy, 23(13), 10. 
About the Author

\section{Kenneth J. Saltman}

University of Massachusetts Dartmouth

ksaltman@umassd.edu

Kenneth J. Saltman teaches in the Educational Leadership and Policy Studies Ph.D. program.

His most recent book is Scripted Bodies: Corporate Power, Smart Technologies, and the Undoing of Public

Education (Routledge, 2016).

\section{About the Guest Editors}

\section{Federico R. Waitoller}

University of Illinois at Chicago

fwaitoll@uic.edu

Dr. Waitoller is an assistant professor in the department of special education at the University of Illinois at Chicago. His research focuses on urban inclusive education. In particular, he examines how neoliberal informed polices, such as top-down accountability, portfolio district models, and school choice converge with inclusive education efforts, and how these initiatives affect Black and Latinx students with dis/abilities. His research also examines teacher learning efforts and pedagogies for inclusive education.

\section{Rhoda Rae Gutierrez}

University of Illinois at Chicago

rrgutier@,uic.edu

Rhoda Rae Gutierrez is a doctoral candidate in Educational Policy Studies at the University of Illinois at Chicago. Her research interests include neoliberal education policy, cultural politics of race, and social justice. She is a researcher with the Collaborative for Equity and Justice in Education and a parent activist. 


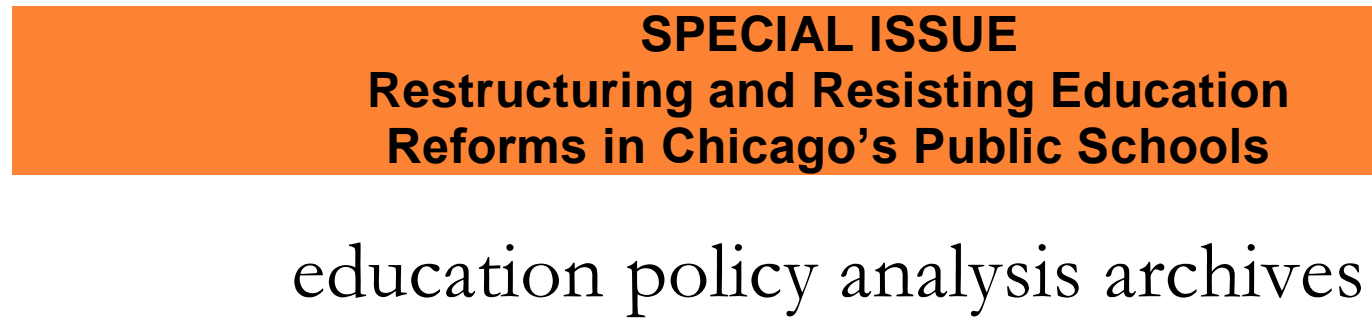

Volume 25 Number 59 June 5, 2017

ISSN 1068-2341

\section{(9)}

SOMERIIGHISRESERVED Readers are free to copy, display, and distribute this article, as long as the work is attributed to the author(s) and Education Policy Analysis Archives, it is distributed for noncommercial purposes only, and no alteration or transformation is made in the work. More details of this Creative Commons license are available at http://creativecommons.org/licenses/by-nc-sa/3.0/. All other uses must be approved by the author(s) or EPAA. EPAA is published by the Mary Lou Fulton Institute and Graduate School of Education at Arizona State University Articles are indexed in CIRC (Clasificación Integrada de Revistas Científicas, Spain), DIALNET (Spain), Directory of Open Access Journals, EBSCO Education Research Complete, ERIC, Education Full Text (H.W. Wilson), QUALIS A1 (Brazil), SCImago Journal Rank; SCOPUS, SOCOLAR (China).

Please send errata notes to Audrey Amrein-Beardsley at Audrey.beardsely@asu.edu

Join EPAA's Facebook community at https://www.facebook.com/EPAAAAPE and Twitter feed@epaa_aape. 


\section{education policy analysis archives editorial board}

Lead Editor: Audrey Amrein-Beardsley (Arizona State University)

Editor Consultor: Gustavo E. Fischman (Arizona State University)

Associate Editors: David Carlson, Margarita Jimenez-Silva, Eugene Judson, Mirka Koro-Ljungberg, Scott

Marley, Jeanne M. Powers, Iveta Silova, Maria Teresa Tatto (Arizona State University)

Cristina Alfaro San Diego State

University

Gary Anderson New York

University

Michael W. Apple University of

Wisconsin, Madison

Jeff Bale OISE, University of

Toronto, Canada

Aaron Bevanot SUNY Albany

David C. Berliner Arizona

State University

Henry Braun Boston College

Casey Cobb University of

Connecticut

Arnold Danzig San Jose State

University

Linda Darling-Hammond

Stanford University

Elizabeth H. DeBray University of Georgia

Chad d'Entremont Rennie Center for Education Research \& Policy

John Diamond University of Wisconsin, Madison

Matthew Di Carlo Albert Shanker Institute

Michael J. Dumas University of California, Berkeley

Kathy Escamilla University of

Colorado, Boulder

Melissa Lynn Freeman Adams State College

Rachael Gabriel

University of Connecticut

Amy Garrett Dikkers University of North Carolina, Wilmington

Gene V Glass Arizona

State University
Ronald Glass University of California, Santa Cruz

Jacob P. K. Gross University of Louisville

Eric M. Haas WestEd

Julian Vasquez Heilig California State University, Sacramento

Kimberly Kappler Hewitt University of North Carolina Greensboro

Aimee Howley Ohio University

Steve Klees University of Maryland

Jaekyung Lee

SUNY Buffalo

Jessica Nina Lester

Indiana University

Amanda E. Lewis University of Illinois, Chicago

Chad R. Lochmiller Indiana University

Christopher Lubienski Indiana University

Sarah Lubienski University of Illinois, Urbana-Champaign

William J. Mathis University of Colorado, Boulder

Michele S. Moses University of Colorado, Boulder

Julianne Moss Deakin

University, Australia

Sharon Nichols University of Texas, San Antonio

Eric Parsons University of Missouri-Columbia

Susan L. Robertson Bristol University, UK

Gloria M. Rodriguez

University of California, Davis
R. Anthony Rolle University of Houston

A. G. Rud Washington State University

Patricia Sánchez University of University of Texas, San Antonio Janelle Scott University of California, Berkeley

Jack Schneider College of the Holy Cross

Noah Sobe Loyola University

Nelly P. Stromquist University of Maryland

Benjamin Superfine University of Illinois, Chicago

Sherman Dorn

Arizona State University

Adai Tefera Virginia

Commonwealth University

Tina Trujillo University of California, Berkeley

Federico R. Waitoller University of Illinois, Chicago

Larisa Warhol

University of Connecticut

John Weathers University of

Colorado, Colorado Springs

Kevin Welner University of Colorado, Boulder

Terrence G. Wiley Center for Applied Linguistics

John Willinsky

Stanford University

Jennifer R. Wolgemuth University of South Florida

Kyo Yamashiro Claremont Graduate University 


\section{archivos analíticos de políticas educativas consejo editorial}

Editor Consultor: Gustavo E. Fischman (Arizona State University)

Editores Asociados: Armando Alcántara Santuario (Universidad Nacional Autónoma de México), Jason Beech (Universidad de San Andrés), Angelica Buendia (Metropolitan Autonomous University, México), Ezequiel Gomez Caride (Pontificia Universidad Católica Argentina), Antonio Luzon (Universidad de Granada), José Luis Ramírez

(Universidad de Sonora, Mexico)

\author{
Claudio Almonacid \\ Universidad Metropolitana de \\ Ciencias de la Educación, Chile \\ Miguel Ángel Arias Ortega \\ Universidad Autónoma de la \\ Ciudad de México \\ Xavier Besalú Costa \\ Universitat de Girona, España
}

Xavier Bonal Sarro Universidad

Autónoma de Barcelona, España

Antonio Bolívar Boitia

Universidad de Granada, España

José Joaquín Brunner Universidad

Diego Portales, Chile

Damián Canales Sánchez

Instituto Nacional para la

Evaluación de la Educación, México

Gabriela de la Cruz Flores

Universidad Nacional Autónoma de

México

Marco Antonio Delgado Fuentes

Universidad Iberoamericana,

México

Inés Dussel, DIE-CINVESTAV,

México

Pedro Flores Crespo Universidad

Iberoamericana, México

Ana María García de Fanelli

Centro de Estudios de Estado y

Sociedad (CEDES) CONICET,

Argentina
Juan Carlos González Faraco

Universidad de Huelva, España

María Clemente Linuesa

Universidad de Salamanca, España

Jaume Martínez Bonafé

Universitat de València, España

Alejandro Márquez Jiménez

Instituto de Investigaciones sobre la

Universidad y la Educación, UNAM,

México

María Guadalupe Olivier Tellez,

Universidad Pedagógica Nacional, México

Miguel Pereyra Universidad de

Granada, España

Mónica Pini Universidad Nacional de San Martín, Argentina

Omar Orlando Pulido Chaves

Instituto para la Investigación

Educativa y el Desarrollo Pedagógico (IDEP)

José Luis Ramírez Romero

Universidad Autónoma de Sonora, México

Paula Razquin Universidad de San

Andrés, Argentina

José Ignacio Rivas Flores

Universidad de Málaga, España

\author{
Miriam Rodríguez Vargas \\ Universidad Autónoma de \\ Tamaulipas, México \\ José Gregorio Rodríguez \\ Universidad Nacional de \\ Colombia, Colombia \\ Mario Rueda Beltrán Instituto \\ de Investigaciones sobre la \\ Universidad y la Educación, \\ UNAM, México \\ José Luis San Fabián Maroto \\ Universidad de Oviedo, \\ España \\ Jurjo Torres Santomé, \\ Universidad de la Coruña, España \\ Yengny Marisol Silva Laya \\ Universidad Iberoamericana, \\ México \\ Juan Carlos Tedesco \\ Universidad Nacional de San \\ Martín, Argentina \\ Ernesto Treviño Ronzón \\ Universidad Veracruzana, México
}

Ernesto Treviño Villarreal

Universidad Diego Portales

Santiago, Chile

Antoni Verger Planells

Universidad Autónoma de

Barcelona, España

Catalina Wainerman

Universidad de San Andrés,

Argentina

Juan Carlos Yáñez Velazco

Universidad de Colima, México 


\section{arquivos analíticos de políticas educativas conselho editorial}

Editor Executivo: Gustavo E. Fischman (Arizona State University)

Editoras Associadas: Geovana Mendonça Lunardi Mendes (Universidade do Estado de Santa Catarina), Marcia Pletsch, Sandra Regina Sales (Universidade Federal Rural do Rio de Janeiro)

\author{
Almerindo Afonso \\ Universidade do Minho \\ Portugal \\ Rosanna Maria Barros Sá \\ Universidade do Algarve \\ Portugal

\section{Maria Helena Bonilla \\ Universidade Federal da Bahia} \\ Brasil \\ Rosa Maria Bueno Fischer \\ Universidade Federal do Rio Grande \\ do Sul, Brasil \\ Alice Casimiro Lopes \\ Universidade do Estado do Rio de \\ Janeiro, Brasil

\section{Suzana Feldens Schwertner \\ Centro Universitário Univates \\ Brasil} \\ Flávia Miller Naethe Motta \\ Universidade Federal Rural do Rio de \\ Janeiro, Brasil
}

Alexandre Fernandez Vaz

Universidade Federal de Santa

Catarina, Brasil

Regina Célia Linhares Hostins

Universidade do Vale do Itajaí,

Brasil

Alfredo Macedo Gomes

Universidade Federal de Pernambuco

Brasil

\section{Jefferson Mainardes}

Universidade Estadual de Ponta

Grossa, Brasil

Jader Janer Moreira Lopes

Universidade Federal Fluminense e

Universidade Federal de Juiz de Fora, Brasil

Debora Nunes

Universidade Federal do Rio Grande do Norte, Brasil

\section{Alda Junqueira Marin}

Pontifícia Universidade Católica de São Paulo, Brasil

Dalila Andrade Oliveira

Universidade Federal de Minas

Gerais, Brasil
José Augusto Pacheco

Universidade do Minho, Portugal

Jane Paiva

Universidade do Estado do Rio de

Janeiro, Brasil

Paulo Alberto Santos Vieira

Universidade do Estado de Mato

Grosso, Brasil

Fabiany de Cássia Tavares Silva

Universidade Federal do Mato

Grosso do Sul, Brasil

António Teodoro

Universidade Lusófona

Portugal

Lílian do Valle

Universidade do Estado do Rio de Janeiro, Brasil

\section{Alfredo Veiga-Neto}

Universidade Federal do Rio

Grande do Sul, Brasil 